\title{
PERLINDUNGAN HUKUM PADA KASUS SUPLEMEN MAKANAN YANG MENGANDUNG BABI
}

\author{
Nabila Emy Mayasari ${ }^{1}$ \\ Program Studi Magister Ilmu Hukum \\ Fakultas Hukum Universitas Diponegoro \\ J alan Imam Bardjo, S.H. No. 1-3, Kampus Pleburan, Semarang 50241 \\ Maynabil74@gmail.com
}

\begin{abstract}
In the development of the business world, there are many cases that harm consumers. One of them is a food supplement that contains pork. This is clearly detrimental to Indonesian consumers, the majority of whom are Muslims. There is no warning on the product that dietary supplements contain pigs which are forbidden by Islam, especially when promoting the use of prominent Islamic scholars in Indonesia. Therefore Law Number 8 of 1999 concerning Consumer Protection which requires following the provisions of halal production is a principle of legal protection for Muslim consumers only aimed at business actors who install halal labels on their products, therefore if the businessman installs a halal label on the product, it must comply with the provisions halal production and to prove that the business actor has produced halally is the existence of a halal certificate.
\end{abstract}

\section{Keywords: Consumers; Food Supplements; Halal.}

\begin{abstract}
ABSTRAK
Dalam perkembangan diduania bisnis, banyak terjadinya kasus yang merugikan konsumenya. Salah satunya adalah suplemen makanan yang mengandung babi. Hal ini jelas merugikan konsumen Indonesia yang mayoritas adalah agama Islam. Pada produk tersebut tidak ada peringatan bahwa suplemen makanan mengandung babi yang diharamkan oleh agama Islam, terlebih lagi saat mempromosikan menggunakan tokoh ulama yang terkenal di Indonesia. Dengan demikian ketentuan Undang-Undang Nomor 8 tahun 1999 tentang Perlindungan Konsumen yang mengharuskan mengikuti ketentuan berproduksi secara halal merupakan asas perlindungan hukum bagi konsumen muslim hanya ditujukankan pada pelaku usaha yang memasang lebel halal pada produknya, oleh karena itu apabila pelaku usaha memasang lebel halal pada produknya harus mengikuti ketentuan berproduksi secara halal dan untuk membuktikan pelaku usaha telah berproduksi secara halal adalah dengan adanya sertifikat halal.
\end{abstract}

Kata Kunci: Konsumen; Suplemen Makanan; Halal.

\footnotetext{
${ }^{1}$ Mahasiswa Program Studi Magister IImu Hukum Universitas Diponegoro
} 
Jurnal Pembangunan Hukum Indonesia

Volume 1, Nomor 1, Tahun 2019
Program Studi Magister Ilmu Hukum Fakultas Hukum Universitas Diponegoro

\section{A. PENDAHULUAN}

Isu paling mengemuka dalam globalisasi adalah penerapan sistem pasar bebas yang saat ini sedang melaju kencang. Keluar-masuknya barang dan jasa melintasi batas negara mempunyai manfaat bagi konsumen, yakni konsumen mempunyai kebebasan untuk memilih barang dan jasa yang ditawarkan. Namun, disisi lain timbul dampak negatif yakni konsumen akan menjadi sasaran para pelaku usaha untuk mendapatkan keuntungan yang sebesar-besarnya.

Produk impor kini mulai membanjiri tanah air kita dengan berbagai jenis produk makanan, baik bahan mentah maupun bahan jadi, dengan harga dan kemasan yang menarik. Masyarakat perlu hatihati dalam memilih produk tersebut, boleh jadi ada yang tersembunyi dibalik produk makanan tersebut yang tidak laik dikonsumsi. Bagi seorang muslim kesalahan dalam memilih produk yang dikonsumsi dapat berujung pada kerugian lahir dan batin. Produk yang mengandung bahan yang berbahaya akan memberikan dampak bagi kesehatan, sedangkan secara batin mengkonsumsi produk yang tidak halal akan menghasil dosa. Hal tersebut mengharuskan masyarakat muslim mencari informasi produk yang akan dikonsumsi tersebut. Cara yang paling mudah adalah dengan teliti membaca label yang melekat pada kemasan produk yang menarik. Beberapa hal yang perlu diteliti oleh konsumen sebelum memutuskan untuk mengkonsumsi suatu produk adalah memahami bahasa/tulisan, nomor pendaftaran, nama produk, produsen dan alamat produksi, label halal, daftar bahan yang digunakan.

Hal ini dapat mengakibatkan pelaku usaha dengan sengaja mengabaikan hak-hak konsumen. Konsumen selalu diposisiskan sebagai pihak lemah, padahal sesungguhnya seorang pengusaha sangat bergantung juga pada konsumen. Contohnya adalah pada kasus suplemen makanan yang telah terbukti mengandung bahan babi yakni Viostin DS yang diproduksi oleh PT. Pharos Indonesia dan Enzyplex oleh PT. Medifarma Laboratories akan tetapi tidak mencantumkan peringatan "mengandung babi" dalam kemasan produk tersebut. Bahaya keamanan pangan yang termasuk kategori berbahaya "yang haram dan atau yang meragukan" efek yang ditimbulkannya memang tidak tampak sebagimana efek dari cemaran kimia, fisik dan mikrobiologi yang langsung berimplikasi pada masalah kesehatan. Bahaya atas kategori halal ini berimplikasi pada ketenangan jiwa konsumen muslim dan sekali tercemar maka tidak dapat dielakan efek kerugiannya cukup besar baik financial maupun kepercayaan konsumen terhadap prosuk tersebut.

Awal mula terjadinya kasus tersebut viralnya surat dari balai badan POM di Mataram kepada balai POM di palangka Raya tentang dua merek suplemen makanan pada sosial media, yang tertera dalam surat tersebut adalah Viostin DS dari PT. Pharos Indonesia dengan Nomor ijin edar (NIE) POM SD. 051523771 nomor bets BN C6K994H dan Enzyplex tablek prosukdi PT Mediafarma Laboratories dengan NIE DBL7214704016A1 nomor bets 16185101. Yang 
Jurnal Pembangunan Hukum Indonesia

Volume 1, Nomor 1, Tahun 2019
Program Studi Magister Ilmu Hukum Fakultas Hukum Universitas Diponegoro kemudian mengambil sampel dan melakukan pengujuan terhadap parameter DNA babi pada dua merek itu .

Labelisasi obat dan makanan ditinjau dari pandangan masyarakat, maka kita akan berhadapan dengan kenyataan bahwa masyarakat, rakyat Indonesia sekitar 90\% nya adalah konsumen muslim. Karenanya keamanan pangan bagi 90\% masyarakat Indonesia harus terpenuhi, maka secara tidak langsung akan menjadi relatif aman pula bagi selain konsumen muslim Indonesia. Bagi konsumen muslim, makanan yang aman tidak hanya sekedar terbebas dari bahaya fisik, kimia ataupun mikrobiologi, tetapi juga ada suatu unsur yang sangat hakiki, yaitu aman dari bahaya barang yang diharamkan dan diragukan. Kemanan, mutu dan gizi pangan sebagaimana amanat UU pangan No.70 tahun 1996 adalah merupakan upaya pemerintah dalam pembangungan pangan untuk memenuhi kebutuhan dasar rakyat Indonesia secara adil dan merata berdasarkan kemandirian dan tidak bertentangan dengan keyakinan masyarakat.

Banyak juga kasus beredarnya produk cacat di masyarakat diakibatkan oleh kurang insentifnya pengujian terhadap produk yang dihasilkan oleh produsen dan juga disebabkan karena lembahnya pengawasan yang dilakukan oleh instansi maupun lembaga yang berwenang menangani masalah pengawasan tersebut (Nggeboe, 2015).

Dalam Kondisi konsumen yang banyak dirugikan, memerluan peningkatan upaya untuk melindunginya, sehingga hak-hak konsumen dapat ditegakkan. Namun sebaliknya, perlu diperhatikan bahwa dalam memberikan pelindungan kepada konsumen, tidak boleh justru mematikan usaha produsen, karena keberadaaan produsen merupakan suatu yang esensial dalam perekonomian negara. Oleh karena itu, ketentuan yang memberikan pelindungan kepada konsumen juga harus diimbangi dengan ketentuan yang memberikan pelindungan kepada produsen, sehingga pelindungan konsumen tidak justru membalik kedudukan konsumen dari kedudukan yang lemah menjadi lebih kuat, dan sebaliknya produsen yang menjadi lemah (Triasih, Heryanti, \& Kridasaksana, 2016).

Dilihat dari penjabaran yang telah disampaikan terlihat bagaimana perlindungan hukum terhadap suplemen makan yang mengandung babi khususnya masyarakat islam di Indonesia dan bagaimana pertanggungjawaban produsen kepada konsumen khususnya konsumen beragama muslim terhadap suplemen makanan yang mengandung babi apabila dilihat dari Undang-Undang 8 Tahun 1998 tentang perlindungan konsumen yang menjadi dasar hukum dalam pembahasan penulisan ini.

Kita juga dapat melihat dari sudut pandang teori perlindungan konsumen dan teori strict liability yang menjadikan dasar dari penelitian ini. Teori perlindungan konsumen Menurut Satjipto Rahardjo, Perlindungan hukum adalah memberikan pengayoman terhadap hak asasi manusia (HAM) yang dirugikan orang lain dan perlindungan itu diberikan kepada masyarakat agar dapat menikmati semua hak-hak yang diberikan oleh hukum. 
Jurnal Pembangunan Hukum Indonesia

Volume 1, Nomor 1, Tahun 2019
Program Studi Magister Ilmu Hukum Fakultas Hukum Universitas Diponegoro
Selanjutnya Phillipus M. Hadjon (Hadjon, 1987) menjelaskan bahwa perlindungan hukum bagi rakyat sebagai tindakan pemerintah yang bersifat preventif dan respresif. Sedangkan teori strict liability adalah prinsip tanggung jawab yang tidak didasarkan pada aspek kesalahan (fault/negligence) dan hubungan kontrak (privity of contract), tetapi didasarkan pada cacatnya produk (objective liability) dan risiko atau kerugian yang diderita konsumen (risk based liability). Dikatakan juga bahwa tujuan utama dari prinsip tanggung jawab mutlak adalah jaminan atas konsekuensi atau akibat hukum dari suatu produk yang mengakibatkan kerugian bagi konsumen (Samsul, 2004). Dari kedua teori perlindungan konsumen dan teori strict liability tersebut produsen dapat menjadikan dasar untuk mempraktekan dalam memproduksi suatu barang dengan baik dan benar. Sehingga tidak ada yang saling merugikan antara produsen maupun konsumen.

Dalam penelitian Perlindungan Hukum Bagi Konsumen Terhadap Produk Pangan Yang Tidak Bersertifikat Halal (Jurnal luS) menyebutkan bahwa Sertifikasi halal bertujuan untuk memberikan kepastian hukum dan perlindungan hukum bagi konsumen, khususnya konsumen muslim. Berdasarkan hasil kajian, perlindungan hukum bagi konsumen terhadap produk pangan yang tidak bersertifikat halal dapat disimpulkan, bahwa Pertama, perlindungan hukum bagi konsumen muslim dari produk pangan yang tidak bersertifikat halal di atur dalam Undang-Undang Nomor 33 Tahun 2014 tentang Jaminan Produk Halal (JPH). Sertifikat halal bersifat wajib (mandatory) sehingga produk pangan yang tidak bersertifikat halal dan berlabel halal tidak bisa lagi beredar di Indonesia, baik yang diproduksi di dalam negeri maupun yang berasal dari luar negeri. Kedua, Pelaku usaha yang telah memperoleh sertifikat halal wajib mencantumkan label halal pada kemasan produk, bagian tertentu dari produk dan/atau tempat tertentu pada produk. Ketiga, Peran pemerintah dalam melakukan pengawasan terhadap beredarnya produk pangan yang tidak bersertifikat halal diatur dalam Undang-Undang Pangan dan Undang-Undang Jaminan Produk Halal (JPH) terutama Penggunaan gelatin telah menyisir hampir setiap produk makanan, minuman, dan obat-obatan. Penggunaan gelatin dalam industri pangan saat ini cukup luas, mulai dari emulasi, pasta, permen lunak, minuman, jelly hingga kapsul (Adisasmito, 2008)

Dilihat dari LPPOM MUI terhadap produk yang bersangkutan, sebaliknya bagi pelaku usaha yang tidak ingin atau belum berkeinginan mencantumkan lebel halal maka ketentuan cara berproduksi secara halal tidak berlaku bagi pengusaha tersebut. Dampak dari ketentuan peraturan perundangan yang tidak mewajibkan (keharusan) produsen untuk mendapatkan sertifikat halal pada LPPOM MUI dari produk makanan dan minuman yang diproduksinya maka terdapat produk makanan dan minuman yang beredar di masyarakat yang tidak berlebel halal sehingga produk tersebut diragukan kehalalannya.

Dengan demikian ketentuan Undang-Undang Nomor 8 tahun 1999 tentang Perlindungan Konsumen yang mengharuskan mengikuti ketentuan 
berproduksi secara halal merupakan asas perlindungan hukum bagi konsumen muslim hanya ditujukankan pada pelaku usaha yang memasang lebel halal pada produknya, oleh karena itu apabila pelaku usaha memasang lebel halal pada produknya harus mengikuti ketentuan berproduksi secara halal dan untuk membuktikan pelaku usaha telah berproduksi secara halal adalah dengan adanya sertifikat halal. Padahal konsumen Muslim wajib mengkonsumsi makanan dan minuman yang halal karena ini merupakan pelaksanaan dari ketentuan syariat Agama Islam yang dalam Undang-Undang Dasar 1945 dijamin dan dilindungi.

\section{B. METODE PENELITIAN}

Metode pendekatan yang digunakan adalah yuridis-normatif, dengan jenis penelitian dogmatik, bentuk penelitian perskriptif hubungan hukum. Spesifikasi penelitian ini yaitu deskriptif-analitis. Metode pengumpulan data yang digunakan melalui metode library research (metode kepustakaan) dengan menguji bahan dokumen dan bahan pustaka yang digunakan dalam penelitian ini.

\section{PEMBAHASAN}

\section{C.1.Perlindungan Konsumen Terhadap Suplemen Makanan Yang Mengandung Babi}

Kesehatan adalah hal yang paling penting bagi setiap manusia didunia. Berbagai jalan ditempuh untuk mendapatkan kesehatan yang sempurna yang bahkan membeli salah satunya suplemen makanan guna memenuhi asupan gizi bagi tubuh. Suplemen makanan adalah produk yang dimaksudkan untuk melengkapi kebutuhan zat gizi makanan, mengandung satu atau lebih bahan berupa vitamin, mineral, asam amino atau bahan lain (Berasal dari tumbuhan atau bukan tumbuhan) yang mempunyai nilai gizi dan atau efek fisiologis dalam jumlah terkonsentrasi ( Keputusan Kepala BPOM Indonesia Nomor HK. 00.05.23.3644 pasal 1 ayat 1).

Viostin DS adalah salah satu suplemen makanan yang ditujukan untuk orang yang memiliki masalah tulang terutama karena adanya pengeroposan tulang dan daerah persendian yang berfungsi sebagai mencegah nyeri sendi, mengatasi gangguan Osteoarthiritis, Suplemen Kesehatan tulang oleh dokter, mengurangi peradangan sendi, membantu pembentukan tulang rawan, membentuk kolagen, menyembuhkan asam urat, mengobati sakit pinggang dan obat rematik. Viostin DS mengandung Glucoosamine, Chondroitin suplhate, manganese, dan beberapa bahan tambahan polivinil pirolidon, talk, magnesium stearat, methocel tartrazin $\mathrm{Cl}$.

Dalam suplemen makanan ini telah ditemukan DNA Babi yang terdapat pada bahan baku suplemen makanan tersebut, hal ini sangat disayangkan bagi para konsumen di Indonesa. Karena Viostin DS telah dikenal dan melakukan pemasaran dengan tokoh agama, dan siaran agama (Islam) yang mengharamkan Babi untuk dikonsumsi. Bahan baku tersebut dipasok oleh pemasok dari spanyol yang telah memiliki sertifikasi halal dari Halal Certification Services IHCS yang telah diakui oleh MUI. Para pihak selaku PT Pharos melakukan penelusuran pada viostin DS dan menemukan sumber pencembaran yang berasal dari salah satubahan 
Jurnal Pembangunan Hukum Indonesia

Volume 1, Nomor 1, Tahun 2019
Program Studi Magister IImu Hukum Fakultas Hukum Universitas Diponegoro baku pembuatan suplemen tersebut yaitu Chondroitin Sulfat yang di peroleh dari pemasok spanyol. Hal ini telah merugikan pihak produksi maupun pihak konsumen yang menggunakan suplemen makan tersebut khususnya masyarakat mulim yang wajib dilindungi oleh hukum sebagai perlindungan konsumen yang telah di atur dalam undang-undang.

Dalam teori perlindungan hukum dikemukakan oleh Salmond yang selanjutnya dijelaskan oleh Fitgerald. Teori ini mengatakan bahwa hukum bertujuan mengintegrasikan dan mengkoordinasikan berbagai kepentingan hukum yang dapat bertabrakan satu sama lain, sehingga dengan hukum yang diintegrasikan sedemikian rupa dapat menekan terjadinya tabrakan kepentingan tersebut. Dalam lalu lintas kepentingan, perlindungan terhadap kepentingan-kepentingan tertentu hanya dapat dilakukan dengan cara membatasi kepentingan di lain pihak. Hukum melindungi kepentingan seseorang dengan cara mengalokasikan suatu kekuasaan kepadanya untuk bertindak dalam rangka kepentingannya sendiri. Pengalokasian kekuasaan ini dilakukan secara terukur, dalam arti ditentukan keluasan dan kedalamannya, sehingga kekuasaan yang demikian yang disebut dengan hak (Rahardjo, 2000).

Pada pasal 1 angka 2 Undang-undang Nomor 8 Tahun 1999 dijelaskan bahwa, konsumen adalah setiap orang pemakai barang danatau jasa yang tersedia dalam masyarakat, naik bagi kepentingan sendiri, keluarga, orang lain, maupun makhluk hidup lain dan tidak untuk diperdagangkan. Dan pelaku usaha merupakan orang atau lembaga yang berbentuk badaan hukum maupun bukan badan hukum yang didirikan dan berkedudukan atau melakukan kegiataan dalam wilayah hukum negara Republik Indonesia, baik sendiri maupun bersamasama melalui perjanjian menyelenggarakan kegiatan usaha dalam berbagai bidang ekonimi (Sari \& Simangungso, 2007).

Sesuai dengan Pasal 3 Undang-undang Perlindungan Konsumen, tujuan dari Perlindungan Konsumen adalah Meningkatkan pemberdayaan konsumen dalam memilih, menentukan dan menuntut hak-haknya sebagai konsumen, Menciptakan sistem perlindungan konsumen yang mengandung unsur kepastian hukum dan keterbukaan informasi serta akses untuk mendapatkan informasi, Menumbuhkan kesadaran pelaku usaha mengenai pentingnya perlindungan konsumen sehingga tumbuh sikap yang jujur dan bertanggungjawab dalam berusaha, Meningkatkan kualitas barang dan/atau jasa yang menjamin kelangsungan usaha produksi barang dan/atau jasa, kesehatan, kenyamanan, keamanan dan keselamatan konsumen.

Selain itu terdapat asas-asas perlindungan konsumen antara lain sebagai berikut: Azas keamanan dan keselamatan konsumen yang merukapan untuk memberikan jaminan atas keamanan dan keselamatan kepada konsumen dalam penggunaan, pemakaian dan pemanfaatan barang dan jasa yang dikonsumsikan. Dan hal ini telah melanggar azas kemanan dan keselamatan 
konsumen, dan tidak menjamin produk yang di produksi, selama 45 tahun telah beredar diwilayah indonesian. Masyarakat umat islam keberatan atas produk tersebut namun dalam kasus ini pelaku usaha telah lalai dalam menjaga kualitas produk tersebut, dan terkontaminasi pada bahan baku suplemen obat, dan apabila Badan POM tidak melakukan uji laboratorium kembali, kemungkinan suplemen makanan itu masih tersebar di wilayah indonesia.

Namun, sebenarnya ini merupakan permasalahan yang butuh perhatian khusus karena dengan banyaknya konsumen yang pernah merasa dirugikan akan hal ini. Pengaturan hak-hak konsumen dalam Pasal 4 melalui Undang-undang No. 8 Tahun 1999 tentang Perlindungan Konsumen menetapkan 3 yaitu Hak atas kenyamanan, keamanan, dan keselamatan dalam mengkonsumsi barang dan/ atau jasa, Hak untuk memilih barang dan/ jasa serta mendapatkan dan kondiai serta jaminan yang dijanjikan, Hak atas informasi yang benar, jelas dan jujur mengenai kondisi dan jaminan barang dan/ atau jasa;

Dari salah satunya hak konsumen yang diberikan di atas, bahwa masalah kenyamanan, keamanan, dan keselamatan konsumen merupakan hal yang paling pokok dan utama dalam perlindungan konsumen (Darnela \& Saraspeni, 2016) .Ada pun kewajiban Konsumen Sesuai dengan Pasal 5 Undang-undang Perlindungan Konsumen, Kewajiban Konsumen adalah : a. Membaca atau mengikuti petunjuk informasi dan prosedur pemakaian atau pemanfaatan barang dan/atau jasa, demi keamanan dan keselamatan;

b. Beritikad baik dalam melakukan transaksi pembelian barang dan/atau jasa;

c. Membayar sesuai dengan nilai tukar yang disepakati;

d. Mengikuti upaya penyelesaian hukum sengketa perlindungan konsumen secara patut.

Banyak hal yang diadukan konsumen akibat ketidakpedulian sebagian pelaku usaha makanan sehingga menimbulkan gangguan kesehatan atau kerugian materil akibat mengonsumsi suatu produk makanan. Gangguan maupun kerugian tersebut terjadinya karena produk yang ditawarkan tidak memenuhi standar kesehatan, kualitas produk yang layak untuk dijual, atau karena tidak adanya informasi yang benar mengenai suatu produk.

Disisi lain Babi adalah sejenis hewan ungulata yang bermancung panjang dan berhidung leper dan dikatakan hewan yang berasal dari Eurasia. Kadang juga dikenali sebagai khinzir (Wijaya, 2009). Konsumen babi sering memilih daging babi yg lemak punggungnya tipis, karena semakin tipis lemak punggungnya, dianggap semakin baik kualitasnya. Sifat lemak punggung babi adalah mudah mengalami oxidative rancidity, sehingga secara struktur kimia sudah tidak layak dikonsumsi.

Penyakit-penyakit yang dapat di timbulkan apabila memakan babi sebagai berikut: Anthrax, Ascaris Suum, Botulism, Brucella Suis, Cryptosporidiosis, Entamoeba Polecki, Erysipelothrix 
Jurnal Pembangunan Hukum Indonesia

Volume 1, Nomor 1, Tahun 2019
Program Studi Magister Ilmu Hukum Fakultas Hukum Universitas Diponegoro
Shusiopathiae, Influenza, Leptospirosis, Pasteurella Aerogenes, Pasteurella Multocida, Pigbel, Rabies, Salmonella Cholerae-suis, Salmonellosis, Sarcosporidiosis, Scabies, Streptococcus Dysgalactiae (group L), Streptococcus Milleri, Streptococcus Suis Type 2 (group R), Swine Vesicular Disease, Taenia Solium, Trichinella Spiralis, Yersinia Enterocolitica, Yersinia Pseudotuberculosis (Wijaya, 2009).

IImu kedokteran mengetahui bahwa babi sebagai rumah dari banyak macam parasit dan penyakit berbahaya, sistem biochemistry babi mengeluarkan hanya $2 \%$ dari seluruh kandungan uric acid, sedangkan 98\% sisanya tersimpan dalam tubuhnya. Apabila konsumen benar-benar akan dilindungi, maka hak-hak konsumen harus dipenuhi, baik oleh negara maupun pelaku usaha, karena pemenuhan hak-hak konsumen tersebut akan melindungi kerugian konsumen dari berbagai aspek. Bertolak dari hak-hak konsumen di atas, hal yang perlu dipertanyakan dari mana hak-hak tersebut diperoleh. Bagaimana hak-hak tersebut dapat dinikmati, dipertahankan dan kapan adanya jaminan perlindungan. Disini juga dilihat pada pasal 10, pelaku usaha yang menawarkan barang/jasa untuk diperdagangkan, dilarang menawarkan, mempromosikan, mengiklankan, atau membuat pernyataan yang tidak benar dan menyesatkan. Pada suplemen makanan ini telah mempromosikan produknya pada acara islam dan tokoh ulama terkenal, sehingga konsumen berangapan bahwa prosuk tersebut halal dan dapat dikonsumsi oleh orang islam (Barkatullah, 2007).

Dalam Pasal 8 Undang-Undang Perlindungan Konsumen disebutkan mengenai perbuatan yang dilarang bahwa:

1. Pelaku usaha dilarang memproduksi dan/atau memperdagangkan barang dan/atau jasa yang tidak memenuhi atau tidak sesuai dengan standar yang dipersyaratkan dan ketentuan peraturan perundang-undangan;

a) Tidak sesuai dengan kondisi, jaminan, keistimewaan atau kemanjuran sebagaimana dinyatakan dalam label, etiket atau keterangan barang dan/atau jasa tersebut

b) Tidak sesuai dengan mutu, tingkatan, komposisi, proses pengolahan, gaya, mode, atau penggunaan tertentu sebagaimana dinyatakan dalam label atau keterangan barang dan/atau jasa tersebut

c) Tidak sesuai dengan janji yang dinyatakan dalam label, etiket, keterangan, iklan atau promosi penjualan barang dan/atau jasa tersebut

d) Tidak mengikuti ketentuan berproduksi secara halal, sebagaimana pernyataan "halal" yang dicantumkan dalam label

e) Tidak mencantumkan informasi dan/atau petunjuk penggunaan barang dalam bahasa Indonesia sesuai dengan ketentuan perundangundangan yang berlaku.

2. Pelaku usaha dilarang memperdagangkan barang yang rusak, cacat atau bekas, dan tercemar tanpa 
Jurnal Pembangunan Hukum Indonesia

Volume 1, Nomor 1, Tahun 2019
Program Studi Magister Ilmu Hukum Fakultas Hukum Universitas Diponegoro memberikan informasi secara lengkap dan benar atas barang dimaksud.

3. Pelaku usaha dilarang memperdagangkan sediaan farmasi dan pangan yang rusak, cacat atau bekas dan tercemar, dengan atau tanpa memberikan informasi secara lengkap dan benar.

4. Pelaku usaha yang melakukan pelanggaran pada ayat (1) dan ayat (2) dilarang memperdagangkan barang dan/atau jasa tersebut serta wajib menariknya dari peredaran

Dalam perlindungan hukum terhadap makanan yang tidak bersertifikat halal ini mendapat pengawasan dari pemerintah dan lembaga-lembaga yang berwenang, seperti Badan Pengawas Obat dan Makanan atau BPOM. Fungsi utama dari badan yang berkaitan dengan sertifikasi halal adalah, melakukan pengawasan terhadap produk yang dikeluarkan produsen apakah sudah mencantumkan label halal atau belum dalam kemasan produknya. BPOM akan mengeluarkan label halal terhadap sebuah produk berdasarkan sertifikat halal yang telah dimiliki oleh produsen atau pelaku usaha. Dengan adanya label halal yang dicantumkan di kemasan suatu produk, akan memudahkan seorang konsumen yang ingin membeli suatu produk melihat dan mengetahui bahwa komposisi yang terkandung dalam produk tersebut adalah halal, sehingga konsumen tidak perlu lagi merasa khawatir dan menduga-duga mengenai komposisi yang terkandung dalam produk tersebut apakah halal atau tidak.

PT Pharos akan berencana untuk mendaftarkan produk halal pada MUI, akan tetapi tidak dapat didaftarkan dan terjadi penemuan DNA Babi terhadap bahan baku Viostin DS. Dalam hal ini pemerintah telah melakukan pengawasan postmarket salah satunya adalah pengambilan sample dan pengujian pada produk.

Pengawasan Obat dan Makanan pasca beredar di masyarakat (post-market) yang telah diatur Peraturan Badan Pengawas Obat Dan Makanan Nomor 28 Tahun 2017 Tentang Rencana Strategis Badan Pengawas Obat Dan Makanan Tahun 2015-2019 adalah:

a. Pengambilan sampel dan pengujian;

b. Peningkatan cakupan pengawasan sarana produksi dan distribusi Obat dan Makanan di seluruh Indonesia oleh 33 Balai Besar (BB)/Balai POM, termasuk pasar aman dari bahan berbahaya;

c. Investigasi awal dan penyidikan kasus pelanggaran di bidang Obat dan Makanan di pusat dan balai.

Kembali pada hukum pelindungan konsumen memiliki tujuan untuk mengangkat harkat kehidupan konsumen, berbagai hal yang membawa akibat negatif dari pemakaian barang dan/atau jasa harus dihindarkan dari aktivitas perdagangan pelaku usaha. Sebaga upaya untuk menghindarkan akibat negatif pemakaian barang dan/atau jasa tersebut, maka dilihat pada pasal 8 ayat 2 yang pada intinya tertuju ada dua hal, yaitu larangan memproduksi barang dan/atau jasa, larangan memperdagangan barang dan/atau jasa yang dimaksud. Dan menurut Nurmadjito yaitu untuk mengupayakan agar barang 
Jurnal Pembangunan Hukum Indonesia

Volume 1, Nomor 1, Tahun 2019
Program Studi Magister Ilmu Hukum Fakultas Hukum Universitas Diponegoro dan/atau jasa yang beredar di masyarakat merupakan produk yang layak edar, antara lain asalusul, kualiyas sesuai dengan informasi pengusaha baik melalui label, etiket, iklan, dan lain sebagainya (Nurmadjito, 2000). Sedangkan suplemen makan tersebut tidak memberikan peringatan label " mengandung babi" dan di iklankan oleh pakar ulama terkenal di indonsia. Pelaku usaha juga dilarang memperdagangkan persediaan farmasin dan pngan yang rusak, cacat atau bekas dan tercemar. Jika pelaku usaha melanggar ketentuan tersebut, barang/jasa tersebut wajib ditarik dari peredaran.

Pada Indonesia, Undang-undang Tentang Perlindungan Konsumen Nomor 8 Tahun 1999 Pasal 1 angka 15, Label pangan atau produk adalah setiap keterangan mengenai pangan yang berbentuk gambar, tulisan, kombinasi keduanya, atau bentuk lain yang disertakan pada pangan, dimasukkan ke dalam, ditempelkan pada atau bagian kemasan pangan. Tujuan pemberian label pada pangan yang di kemas adalah agar masyarakat yang membeli dan atau mengkonsumsi pangan memperoleh informasi yang benar dan jelas tentang setiap produk pangan yang di kemas, baik menyangkut asal, kemasan, mutu, kandungan gizi maupun keterangan lain yang diperlukan sebelum memutuskan akan membeli dan atau mengkonsumsi pangan tersebut. Ketentuan ini berlaku bagi pangan yang telah melalui proses pengemasan akhir dan siap untuk diperdagangkan (prepackaged), tetapi tidak berlaku bagi perdagangan pangan yang di bungkus di hadapan pembeli.
Penggunaan label dalam kemasan selalu berkaitan dengan aspek perdagangan.

Dalam UU Kesehatan No 36 Tahun 2009, Perlindungan hukum yang dijelaskannya adalah dalam bentuk upaya kesahatan. Upaya kesehatan sendiri dijelaskaan dalam pasal 1 angka 11 bahwa Setiap kegiatan dan/atau serangkaian kegiatan yang dilakukan secara terpadu, terintregasi dan berkesinambungan untuk memelihara dan meningkatkan derajat kesehatan masyarakat dalam bentuk pencegahan penyakit, peningkatan kesehatan, pengobatan penyakit, dan pemulihan kesehatan oleh pemerintah dan/atau masyarakat. Artinya dalam memebentuk masyarakat yang sehat dan sejahtera maka perlulah peran pemerintah dalam mencegah, meningkatkan kesehatan dan perlindungan kesehatan.

UU Kesehatan 36 Tahun 2009 menjelaskan dalam pasal 106 ayat (2) yang berbunyi, Pemerintah berwenang mencabut izin edar dan memerintahkan penarikan dari peredaran sediaan farmasi dan alat kesehatan yang telah memperoleh izin edar, yang kemudian terbukti tidak memenuhi persyaratan mutu dan/atau keamanan dan/atau kemanfaatan, dapat disita dan dimusnahkan sesuai dengan ketentuan peraturan perundang-undangan. Pasal 106 ayat (2) tersebut tidak menjelasakan mengenai sediaan farmasi yang tidak memiliki izin edar, peraturan yang dijelaskan hanya mengenai sediaan farmasi yang memiliki izin edar untuk dapat ditarik dari peredaran apabila tidak memenuhi persyaratan (Ilham, 2015). 
Jurnal Pembangunan Hukum Indonesia

Volume 1, Nomor 1, Tahun 2019
Program Studi Magister Ilmu Hukum Fakultas Hukum Universitas Diponegoro
Larangan-larangan yang tertuju pada " produk" sebagaimana dimaksudkan adalah untuk memberikan pelindungan terhadap kesehatan/harta konsumen dari penggunaan barang dengan kualitas yang dibawah standar atau kualitas yang lebih rendah daripada nilai harga yang dibayar. Dengan adanya pelindungan yang demikian, maka konsumen tidak diberikan barang yang kualitas yang lebih rendah daripada haraga yang dibayarkan, atau yang tidak sesuai dengan informasi yang diperoleh.(Miru \& Yodo, 2015)

Dalam UUPK tidak ditemukan ketentukan yang khusus yang menyebutkan bahwa untuk melindungi kesehatan konsumen, dan hanya menyebutkan kata keamanan dan keselamatan konsumen pada uraian tentang asas pelindungan konsumen dan hak-hak konsumen, tanpa uraian lebih lanjut, namun ketetuan yang lebih dapat menjabarkan prinsip pelindungan kesehatan/harta konsumen tersebut dapat juga dimaksudkan memberikan pelindungan kepada konsumen diantaranya pasal 21 UU kesehatan dan pada Peraturan Pemerintah No 69 Tahun 1999 tentang label dan iklan pangan. Keterangan halal tersebut dimaksudkan agar masyarakat (umat islam) terhindar dari mengonsumi pangan yang tidak halal.

Memproduksi suatu barang alangkah baiknya kita mendaftarkan makanan tersebut kepada Badan POM agar dapat meyakinkan bahwa suplemen tersebut dapat dikonsumsi dan diedarkan diseluruh Indonesia, adapun mekanisme pendaftaran pom sebagai berikut: Konsumsi suplemen makanan yang mengandung babi yang di indonesia mayoritas bergama islam, walaupun secara ilmiah itu untuk baik untuk dikonsumsi, namun konsumen yang beragama islam masih membutuhkan persyaratan lain yang dapat menenteramkan batinnya. Pelindungan kesehatan manusia dengan cara yang dapat dipertanggung jawabkan secara ilmiah, tentu dengan mudah dapat diterima oleh para anggota, namun diperlukan pula suatu tindakan pelindungan kesehatan batin) yang walaupun secara ilmiah sulit (bahkan mungkin tidak dapat) dibuktikan, namun sangat besar pengaruhnya terhadap kesehatan (rohani) atau ketenteraman batin konsumen (Miru, 2011).

Bagi konsumen muslim ketentuan mengenai informasi halal suatu produk pangan merupakan hal penting, karena menyangkut pelaksanaan syariat, juga menjadi hak konsumen muslim. Jadi, pemberian sertifikasi halal bertujuan untuk memberikan kepastian hukum dan perlindungan hukum bagi konsumen. Undang-undang Nomor 18 Tahun 2012 tentang Pangan terdapat beberapa pasal yang terkait dengan kehalalan produk pangan yaitu pasal 97 ayat (1), (2) dan (3). Adapun bunyi pasal tersebut adalah sebagai berikut : Pasal 97

1) Setiap orang yang memproduksi Pangan di dalam negeri untuk diperdagangkan wajib mencantumkan label di dalam dan/atau pada Kemasan Pangan

2) Setiap orang yang mengimpor pangan untuk diperdagangkan wajib mencantumkan label di dalam dan/ atau pada kemasan pangan pada saat 
memasuki wilayah Negara Kesatuan Republik Indonesia.

3) Pencantuman label di dalam dan/atau pada kemasan Pangan sebagaimana dimaksud pada ayat (1) dan ayat (2) ditulis atau dicetak dengan menggunakan bahasa Indonesia serta memuat paling sedikit keterangan mengenai :

a. Nama produk;

b. Daftar bahan yang digunakan;

c. Berat bersih dan isi bersih;

d. Nama dan alamat pihak yang memproduksi atau mengimpor;

e. Halal bagi yang dipersyaratkan;

f. Tanggal dan kode produksi;

g. Tanggal,bulan dan tahun kadaluarsa;

h. Nomor izin edar bagi Pangan Olahan

Ketentuan lain yang mengatur label kehalalan suatu produk diatur dalam peraturan pelaksana, seperti dalam Peraturan Pemerintah Republik Indonesia Nomor 69 Tahun 1999 Tentang Label Dan Iklan Pangan, Keputusan Menteri Kesehatan RI Nomor : 924/Menkes/SK/VIII/1996 tentang Perubahan atas Keputusan Menteri Kesehatan RI Nomor : 82/Menkes/SK/I/1996 tentang Pencantuman Tulisan Halal Pada Label Makanan, Keputusan Menteri Agama R.I.Nomor 518 Tahun 2001 Tanggal 30 Nevember 2001 Tentang Pedoman Dan Tata Cara Pemeriksaan Dan Penetapan Pangan Halal Menteri Agama Republik Indonesia, Surat Keputusan Lembaga Pengkajian Pangan, Obat-obatan dan Kosmetika MUI, Nomor : SK74/Dir/LPPOM MUI/XI/09 tentang Peraturan Sertifikasi yang diajukan distributor. Dalam pegajuan ijin badan POM kita dapat melihat bahwa adanya data-data tentang yang berkaitan dengan produk tersebut. $\mathrm{Hal}$ ini telah dinyatakan lulus dan tidak mengandung hal-hal yang dilarang oleh Badan POM.

Dengan demikian apabila mendasarkan pada ketentuan Pasal 4 huruf $c$ dan Pasal 7 hurub b Undang-undang Nomor 8 tahun 1999 tentang Perlindungan Konsumen, Konsumen Muslim mendapatkan perlindungan konsumen, namun apabila ketentuan tersebut dihubungkan dengan ketentuan Pasal 8 ayat (1) huruf h Undang-undang Nomor 8 tahun 1999 tentang Perlindungan Konsumen, yang menentukan bahwa : Pelaku usaha dilarang memproduksi dan/atau memperdagangkan barang dan/atau jasa yang tidak mengikuti ketentuan berproduksi secara halal, sebagaimana pernyataan "halal" yang dicantumkan dalam label.

Pentingnya aspek legal labelisasi obat dan makanan, tekait dengan tuntutan konsumen yang terus meningkat khususnya mengenai aspek kehalalan ini. Secara hukum masalah ini telah diatur oleh pemerintah baik dalam undang-undang pangan, undang-undang perlindungan konsumen maupun peraturan pemerintah yang mengatur secara lebih teknis.

Sebelumnya anggapan atas labelisasi pada produk makanan merupakan hal yang menyulitkan dan prosedur yang bertele-tele bagi produsen, namun untungnya hal ini dapat diklarifikasi, dimana hanya kejujuran dan keterbukaanlah hal yang paling utama dalam labelisasi terhadap produk makanan ini. 
Dengan adanya sertifikasi halal pada produk memperoleh sertifikat halal, atau memberi penolakan makanan yang menjadi konsumsi masyarakat, bagi yang tidak mengantongi sertifikat halal. merupakan salah satu upaya perlindungan Kerjasama itu, jelas memberikan kepastian bagi pemerintah terhadap 90\% masyarakat konsumen konsumen muslim dalam mengkonsumsi produk muslim, namun selain dilihat dari sudut keyakinan masyarakat, labelisasi atas produk makanan dan obat yang beredar di masyarakat dapat menunjukan bahwa makanan dan obat tersebut juga layak dikonsumsi baik oleh kaum muslim mapun nonmuslim.

LPPOM MUI akan melakukan melakukan pelabelan dengan syarat harus menyertakan lampiran bahan baku, dokumen pendukung bahan baku, serta bahan menu sebuah produk barang yang beredar dipasaran apabila adanya permintaan produsen untuk mencantumkan label halal, karena kehalalan tidak wajib untuk dicantumkan pada kemasan. Apalagi, sejak Direktorat Pengawasan Obat dan Makanan (sekarang Badan POM) menyerahkan sepenuhnya urusan kehalalan ini pada LPPOM MUI. Sebelumnya, memang ada dua model sertifikasi halal, dari MUI dan Direktorat POM. Namun belakangan, BPOM telah menyerahkan sepenuhnya sertifikasi halal ini kepada Komisi Fatwa MUI. Pemberian atau penolakan sertifikat halal sepenuhnya berada di MUI, namun BPOM memiliki peran melalui kegiatan evaluasi terhadap keamanan, manfaat, dan mutu produk sebelum beredar (pre-market evaluation) dan pengawasan selama produk di peredaran (post-market vigilance) untuk mesetujui pelabelan halal. Berdasarkan fatwa MUI ini, BPOM akan memberi persetujuan pencantuman label halal bagi yang makanan. Kerjasama Depkes - LPPOM MUI sudah sampai pada taraf menjamin suatu produk halal dan thoyib. Dari segi agama aman, dari segi kesehatan pun demikian. Bagi konsumen dan produsen, satu pintu sertifikasi halal ini memang menguntungkan. Setidaknya tidak banyak meja yang harus dilalui, yang artinya menghemat biaya sehingga tidak perlu dibebankan kepada konsumen. Namun sejauh ini, belum ada angka pasti untuk mengukur tingkat kepedulian konsumen Muslim terhadap produk halal ini. Yang berkepentingan terhadap sertifikat halal itu sebetulnya bukan hanya konsumen saja, tetapi juga produsen. Bagi masyarakat Indonesia yang tingkat intelektualitasnya semakin bagus dan makin kritis, produk halal menjadi keharusan (Adisasmito, 2008).

Sistem labelisasi yang dilakukan oleh MUI dan BP-POM ini merupakan kegiatan yang dapat dipertanggungjawabkan. Pemberian labelisasi produk obat dan makanan tersebut harus melalui proses yang sangat ketat, dan evaluasi yang kontinu. Setidaknya, ada delapan jenis informasi yang bisa diketahui dari label kemasan produk pangan. Yakni sertifikasi halal, nama produk, kandungan isi, waktu kedaluwarsa, kuantitas isi, identifikasi asal produk, informasi gizi, dan tanda-tanda kualitas lainnya. Informasi-informasi ini mesti diperhatikan dengan seksama supaya konsumen tidak salah beli. 
Jurnal Pembangunan Hukum Indonesia

Volume 1, Nomor 1, Tahun 2019
Program Studi Magister Ilmu Hukum Fakultas Hukum Universitas Diponegoro
Pengawasan terhadap penyelenggara perlindungan konsumen dan penerapan ketentuan peraturan perundang-undangannya dilaksanakan oleh pemerintah, masyarakat dan LPKSM (Lembaga Pengawas Konsumen Swadaya Masyarakat). Pengawasan pemerintah dilakukan oleh menteri dan/atau menteri teknis terkait, sedangkan pengawasan oleh masyarakat dan LPKSM dilakukan secara langsung terhadap barang dan/atau jasa yang beredar di pasar. Karena itu jika dari hasil pengawasan terjadi penyimpangan yang membahayakan konsumen maka pelakunya dapat dikenai sangsi sesuai peraturan perundangundangan yang berlaku.

Menurut Pasal 30 UU Perlindungan Konsumen tentang pengawasan terhadap perlindungan konsumen adalah:

1) Pengawasan terhadap penyelenggaraan perlindungan konsumen, serta penerapan ketentuan peraturan perundang-undangan nya diselenggarakan oleh pemerintah, masyarakat, dan lembaga perlindungan konsumen swadaya masyarakat.

2) Pengawasan oleh pemerintah sebagaimana dimaksud pada ayat (1) dilaksanakan oleh menteri dan atau menteri teknis terkait

3) Pengawasan oleh masyarakat dan lembaga perlindungan konsumen swadaya masyarakat dilakukan terhadap barang dan atau jasa yang beredar di pasar

4) Apabila hasil pengawasan sebagaimana dimaksud ayat (3) ternyata menyimpang dari peraturan perundang-undangan yang berlaku dan membahayakan konsumen, menteri dan atau menteri teknis mengambil tindakan sesuai dengan peraturan perundang-undangan yang berlaku

5) Hasil pengawasan yang diselenggarakan masyarakat dan lembaga perlindungan swadaya masyarakat dapat disebarluaskan kepada masyarakat dan dapat disampaikan kepada menteri dan menteri teknis

6) Ketentuan pelaksanaan tugas pengawasan sebagaimana dimaksud pada ayat (1), ayat (2), dan ayat (3) ditetapkan dengan peraturan pemerintah. Pengawasan terhadap barang dan/ jasa dilakukan dengan cara melakukan penelitian, pengujian dan/atau survei. Aspek pengawasan meliputi pemuatan informasi tentang resiko penggunaan barang jika diharuskan pemasangan label, pengiklanan dan lain-lain yang diisyaratkan berdasarkan ketentuan peraturan perundangundangan dan kebiasaan dalam praktek dunia usaha (Asri, 2016).

Pengawasan pangan dimaksudkan untuk memberikan jaminan keamanan pangan yang dikonsumsi oleh masyarakat. Pemerintah melakukan fungsi pengawasan terhadap produk pangan yang beredar, yang dituangkan dalam Pasal 108 UndangUndang Nomor 18 Tahun 2012 yaitu sebagai berikut:

1) Dalam melaksanakan penyelenggaraan pangan, pemerintah berwenang melakukan pengawasan,

2) Pengawasan sebagaimana dimaksud pada ayat (1) dilakukan terhadap pemenuhan : 
Jurnal Pembangunan Hukum Indonesia

Volume 1, Nomor 1, Tahun 2019
Program Studi Magister Ilmu Hukum Fakultas Hukum Universitas Diponegoro a. Ketersediaan dan/atau kecukupan pangan pokok yang aman, bergizi, dan terjangkau daya beli masyarakat: dan

b. Persyaratan keamanan pangan, mutu pangan dan gizi pangan serta persyaratan label dan iklan pangan

3) Pengawasan terhadap :

a. Ketersediaan dan/atau kecukupan pangan pokok sebagaimana dimaksud pada ayat (2) huruf a dilaksanakan oleh lembaga pemerintah yang menyelenggarakan urusan pemerintahan dibidang pangan

b. Persyaratan kemanan pangan, mutu pangan dan gizi pangan, serta perysratan label dan iklan pangan sebagaimana dimaksu pada ayat (2) huruf b, untuk pangan olahan, dilaksanakan oleh lembaga pemerintah yang melaksanakan tugas pemerintah di bidang pengawasan obat dan makanan

c. Persyaratan keamanan pangan, mutu pangan, dan gizi pangan serta persyaratan label dan iklan pangan sebagaiimana dimaksud ayat (2) huruf $b$, untuk pangan segar, dilaksanakan oleh lembaga pemerintah yang menyelenggarakan urusan pemerintah di bidang pangan

4) Pemerintah menyelenggarkan progran pemantauan, evaluasi dan pengawasan secara berskala terhadap kegiatan atau proses produksi, penyimpanan, pengangkutan dan/atau peredaran pangan oleh pelaku usaha pangan.
Jadi perlindungan hukum terhadap produk pangan yang tidak sesuai dengan komposisi pada table informasi ini mendapat pengawasan dari lembaga-lembaga yang berwenang seperti Badan Pengawas Obat dan Makanan atau BPOM. Perlindungan hukum bagi konsumen muslim di Indonesia secara umum ditunjukkan melalui adanya Undang-Undang Nomor 8 Tahun 1999 tentang Perlindungan konsumen. Khususnya dalam penelitian ini, pelaku usaha telah mendapatkan sanksi Hukum Administrasi yaitu yang berfungsi untuk mencegah (preventive) oleh pemerintah daerah terkait. Tetapi konsumen muslim yang dirugikan tidak mendapatkan hak atas ganti rugi atau kompensasi sebagaimana yang diatur dalam Pasal 4 Undang-Undang Nomor 8 tentang Perlindungan Konsumen

\section{C.2. Tanggung Jawab Pelaku Usaha dalam Melindungi Konsumen}

Tanggung jawab pelaku usaha diambil dari kata dasar dari pertanggung jawaban, yang berarti keadaan wajib menanggung segala sesuatu yang terjadi. Istilah yang berkaitan dengan pertanggung jawaban dalam kamus hukum, yaitu liability, yang merupakan istilah hukum yang luas yang menunjuk hampir semua karakter risiko atau tanggung jawab, yang pasti, yang bergantung atau yang meliputi semua karakter hak dan kewajiban secara aktual seperti kerugian, ancaman, kejahatan, biaya atau kondisi yang menciptakan tugas untuk melaksanakan undang-undang, dan responbility, yang berarti hal yang dapat dipertanggungjawabkan atas suatu 
Jurnal Pembangunan Hukum Indonesia

Volume 1, Nomor 1, Tahun 2019
Program Studi Magister Ilmu Hukum Fakultas Hukum Universitas Diponegoro kewajiban, dan termasuk putusan, keterampilan, kemampuan dan kecakapan meliputi juga kewajiban bertanggung atas undang-undang yang dilaksanakan (Andriyani, 2016). Prinsip tanggung jawab mutlak (Strict liability) yang lebih cocok dalam kasus PT Pharos. Prinsip tanggung jawab mutlak adalah prisip tanggungjawab yang menetapkan kesalahan tidak sebagai faktor yang menetukan. Namun ada pengecualian-pengecualian yang memungkinkan untuk dibebaskan dari tanggungjawab misalnya force majeur (Andriyani, 2016).

PT Pharos harus bertanggung jawab diperlukan analisis seberapa jauh tanggung jawab yang dibebankan kepada PT Pharos. Prinsip tanggung jawab merupakan perihal yang sangat penting dalam hukum perlindungan konsumen berdaasarkan prinsip tanggung jawab pelaku usaha dikenal adanya presumption of liability atau prinsip praduga untuk selalu bertanggung jawab sampai PT Pharos dapat membuktikan tidak bersalah sehingga beban pembuktian ada pada PT tersebut.

Undang-undang tentang Perlindungan Konsumen tidak memberikan rumusan yang jelas dan tegas tentang definisi dari jenis barang yang secara hukum dapat dipertanggungjawabkan, dan sampai seberapa jauh suatu pertanggungjawaban atas barang tertentu dapat dikenakan bagi pelaku usaha tertentu atas hubungan hukumnya dengan konsumen. Hal ini erat kaitannya dengan konsep Product Liability yang banyak dianut oleh negaranegara maju.
Sehubungan dengan hal tersebut di atas maka ada dua hak konsumen yang berhubungan dengan Product Liability sebagaimana Adrian Sutedi dalam bukunya Tanggung Jawab Produk Dalam Hukum Perlindungan Konsumen, menyebutkan bahwa:

1. Hak untuk mendapatkan barang yang memiliki kuantitas dan kualitas yang baik serta aman. Dengan hak ini berarti konsumen harus dilindungi untuk mendapatkan barang dengan kuantitas dan kualitas yang bermutu. Ketidaktahuan konsumen atas suatu produk barang yang dibelinya sering kali diperdayakan oleh pelaku usaha. Konsumen sering dihadapkan pada kondisi "jika setuu beli, jika tidak silahkan cari di tempat yang lain". Dalam situasi yang demikian, biasanya konsumen terpaksa mencari produk alternatif (bila masih ada), yang mungkin kualitasnya lebih buruk.

2. Hak untuk mendapatkan ganti kerugian. Jika barang yang dibelinya dirasakan cacat, rusak, atau telah membahayakan konsumen, ia berhak mendapatkan ganti kerugian yang pantas. Namun, jenis ganti kerugian yang diklaimnya untuk barang yang cacat atau rusak, tentunya harus sesuai dengan ketentuan yang berlaku atau atas kesepakatan masing-masing pihak, artinya konsumen tidak dapat menuntut secara berlebihan dari barang yang dibelinya dengan harga yang dibayarnya, kecuali barang yang dikonsumsinya itu menimbulkan gangguan pada tubuh atau mengakibatkan cacat pada tubuh konsumen, maka tuntutan konsumen dapat melebihi dari harga barang yang dibelinya. 
Jurnal Pembangunan Hukum Indonesia

Volume 1, Nomor 1, Tahun 2019
Program Studi Magister Ilmu Hukum Fakultas Hukum Universitas Diponegoro
Berbicara mengenai akibat hukum bagi pelaku usaha yang menjual atu memproduksi label halal konsumen muslim maka akibat hukum bagi pelaku usaha tersebut akan berbentuk tanggung jawab pelaku usaha tersebut terhadap konsumen, dimana tanggung jawab pelaku usaha tersebut berupa tanggung jawab produk. Tanggung jawab produk dapat diartikan sebagai tanggung jawab produsen untuk produk yang dibawanya ke dalam peredaran, yang menimbulkan atau menyebabkan kerugian karena cacat yang melekat pada produk tersebut. Tanggung jawab meliputi baik tanggung jawab kontraktual/berdasarkan suatu perjanjian maupun tanggung jawab perundang-undangan/berdasarkan perbuatan melawan hukum. Berkenaan dengan tanggung jawab produk, dapat ditemukan dalam Pasal 19 Ayat (1) dan Ayat (5)serta Pasal 28 Undang-Undang Nomor 8 Tahun 1999 Tentang Perlindungan Konsumen. Pasal 19 Ayat (1) dan Ayat (5) Undang-Undang Nomor 8 Tahun 1999 Tentang Perlindungan Konsumen. Pada Pasal 19 Ayat 1 menyatakan: "Pelaku usaha bertanggung jawab memberikan ganti rugi atas kerusakan, pencemaran, dan/atau kerugian konsumen akibat mengkonsumsi barang dan/atau jasa yang dihasilkan atau diperdagangkan" dan ayat 2 menyebutkan bahwa "Ganti rugi sebagaimana dimaksud pada ayat (1) dapat berupa pengembalian uang atau penggantian barang dan/atau jasa yang sejenis atau setara nilainya, atau perawatan kesehatan dan/atau pemberian santunan yang sesuai dengan ketentuan peraturan perundang-undangan yang berlaku".
Ganti rugi merupakan bagian dari tanggungjawab pihak yang menyebabkan kerugian baik itu kerugian nyata yang telah terjadi, atau kerugian yang diduga akan timbul di kemudian hari, terhadap pihak yang dirugikan. Tanggung jawab ini lahir karena seandainya tidak terjadi kesalahan yang menyebabkan suatu pihak merugi, tentu tidak akan lahir tanggung jawab untuk mengganti rugi terhadap suatu kerugian (Fadhly, 2013).

Husaini Kadir melihat ada tiga alasan gugatan ganti rugi, yaitu (Rusli, 2012) :

a. Karena wanprestasi berdasarkan hubungan jual beli.

b. Karena perbuatan melanggar hukum ex Pasal 1365 KUHPerdata.

c. Karena cacat pada produk

Dalam kenyataannya, konsumen Indonesia masih sering mengalami kasus-kasus yang sangat merugikan dirinya, baik secara materiil maupun immateriil. Kerugian yang diderita konsumen sebagai akibat dari pemakaian barang-barang konsumsi itu dapat diklasifikasikan ke dalam Kerugian inmateriil, yaitu kerugian yang membahayakan kesehatan dan/atau jiwa konsumen. Ganti rugi atas kerugian yang diderita konsumen pada hakikatnya berfungsi sebagai :

1. Pemulihan hak-haknya yang telah dilanggar;

2. Pemulihan atas kerugian materiil maupun inmateriil yang telah dideritanya;

3. Pemulihan pada keadaan semula.

Dalam Pasal diatas menyatakan bahwa menurut penulis PT Pharos telah lalai dalam 
Jurnal Pembangunan Hukum Indonesia

Volume 1, Nomor 1, Tahun 2019
Program Studi Magister Ilmu Hukum Fakultas Hukum Universitas Diponegoro menjaga, mengcek bahan baku sehingga pengolahan Viostin DS terkontaminasi DNA Babi pada saat pengiriman ke Indonesia. Dan menurut pendapat penulis, PT Pharos ada itikad baik untuk mendaftarkan produk tersebut pada MUI akan kehalalnya. Dan menurut saya PT Pharos harus bertanggungjawab kepada konsumen yang dirugikan dengan memberikan ganti rugi sebagaimana Pasal 19 Ganti rugi sebagaimana dimaksud pada ayat (1) dapat berupa pengembalian uang atau penggantian barang dan/atau jasa yang sejenis atau setara nilainya, atau perawatan kesehatan dan/atau pemberian santunan yang sesuai dengan ketentuan peraturan perundang-undangan yang berlaku.:

UUPK mengatur bahwa ganti rugi dapat dilakukan melalui beberapa mekanisme diantaranya:
a. Pengembalian uang
b. Perawatan kesehatan
c. Pemberian santunan yang sesuai dengan ketentuan peraturan perundang-undangan yang berlaku

Dalam hukum tentang product liability pihak korban atau konsumen yang akan menuntut ganti kerugian, pada dasarnya hanya diharuskan menunjukan 3 hal, yaitu (Nurbaiti, 2013):

a. Produk tersebut memang telah cacat pada waktu diserahkan oleh produsen

b. Cacat tersebut telah menyebabkan atau turut menyebabkan kerugian atau kecelakaan

c. Adanya kerugian. Akan tetapi juga diakui secara umum bahwa pihak korban atau konsumen aharus menunjukan bahwa pada waktu terjadinya kerugian, produksi tersebut pada prinsipnya berada dalam keadaan seperti waktu diserahkan oleh produksen, artinya tida diadakan modifikasimodifikasi oleh konsumen.

Pada pasal 1246 KUHPerdata, ganti rugi terdiri dari faktor yaitu kerugian yang nyata-nyata diderita. Penentuan ganti rugi pun dapat dilakukan dengan memperhitungkan: Pertama, manfaat yang akan diperoleh dengan menghitung seluruh kerugian yang diderita oleh korban, Kedua, Pengurangan ganti rugi uang bagi korban, apabila kerugian tersebut disebabkan pula oleh korban.

Penunjukkan Pasal 19 ayat (2) UUPK kepada peraturan perundang-undangan sebagai pedoman, maka dapat dikemukakan ketentuan KUHPerdata. Penentuan tersebut untuk menunjukkan besarnya jumlah ganti rugi, KUHPerdata memberikan pedoman, yaitu (Miru \& Yodo, 2015):

1. Besarnya ganti kerugian sesuatu dengan fakta tentang ganti kerugian yang benar-benar terjadi dan dialami oleh konsumen;

2. Besarnya kerugian dapat dituntut adalah kerugian, yang merupakan akibat langsung dari peristiwa yang terjadi, yaitu sebagai akibat dari peristiwa perbuatan melawan hukum;

Selanjutnya pada pasal 19 (3) menjelaskan bahwa Pemberian ganti rugi dilaksanakan dalam tenggang waktu 7 (tujuh) hari setelah tanggal transaksi. Pada ayat 4 Pemberian ganti rugi sebagaimana dimaksud pada ayat (1) dan ayat (2) tidak menghapuskan kemungkinan adanya tuntutan pidana berdasarkan pembuktian lebih lanjut 
mengenai adanya unsur kesalahan. Dan Ketentuan sebagaimana dimaksud pada ayat (1) dan ayat (2) tidak berlaku apabila pelaku usaha dapat membuktikan bahwa kesalahan tersebut merupakan kesalahan konsumen telah diatur pada ayat 5 .

Akan tetapi belum terlihat adanya yang mengajukan ganti rugi kepada PT Pharos dalam pemakaian produk Viostin Ds. Dikarenakan bahwa rata-rata konsumen tidak terlalu perduli dan cenderung menerima dan transaksi lebih dari 7 hari kerja sehingga lebih cenderung menerima putusan dan dibekali informasi bahwa produk tersebut mengandung babi. Tanggung jawab lain yang dilakukan adalah dengan suka rela PT Pharos melakukan penarikan produk yang ada di pemasaran. Dalam memproduksi barang atau jasa, pelaku usaha tidak hanya semata-mata mencari keuntungan yang sebesar-besarnya, tetapi juga harus memperhatikan kepentingan konsumen. Maka dari itu, selain memiliki hak, pelaku usaha juga dituntut akan tanggung jawabnya. Pelaku usaha juga mempunyai kewajiban pada pasal 7 Undang-Undang Perlindungan konsumen harus beritikad baik dalam melakukan kegiatan usahanya, memberikan informasi yang benar, jelas dan jujur mengenai kondisi jaminan barang dan/atau jasa serta memberikan kejelasan pengguna, perbaikan dan pemeliharaan, menjami mutu barang dan memberikan kompensasi, ganti akibat kerugian akibat penggunaan, pemakaian dan pemanfaatan barang dan/atau jasa yang diperdagangkan. Sehingga pelaku usaha wajib memberikan kompensasi kepada konsumen apabila, konsumen mengajukan pengajuan atas barang yang cacat yang jelas telah merugikan dan tidak sesuai dengan pemanfaatan pada suplemen makanan tersebut.

\section{KESIMPULAN}

Dari pemaparan penulis diatas dapat diambil kesimpulan yaitu:

a. Perlindungan hukum terhadap produk pangan yang tidak sesuai dengan komposisi pada table informasi ini mendapat pengawasan dari lembaga-lembaga yang berwenang seperti Badan Pengawas Obat dan Makanan atau BPOM. Perlindungan hukum bagi konsumen muslim di Indonesia pada kasus ini yang karena tidak sesuai dengan informasi pada petunjuk menu, secara umum ditunjukkan melalui adanya Undang-Undang Nomor 8 Tahun 1999 tentang Perlindungan konsumen, Undang-Undang Pangan Nomor 18 Tahun 2012 pada pasal 19 ayat 3, Undang-Undang Kesehatan 36 Tahun 2009 pasal 21. Khususnya dalam penelitian ini, pelaku usaha telah mendapatkan sanksi Hukum Administrasi yaitu yang berfungsi untuk mencegah (preventive) oleh pemerintah daerah terkait. Yang telah diatur pada Peraturan Kepala Badan Pengawas Obat Dan Makanan Nomor 22 Tahun 2017 Tentang Penarikan Pangan Dari Peredaran.

b. Dalam Tanggung jawab produsen yang disini adalah PT Pharos sesuai dengan UU 8 tahun 1999 yaitu Pengembalian uang, perawatan kesehatan, pemberian santunan yang sesuai 
dengan ketentuan peraturan perundangundangan yang berlaku. Akan tetapi tetapi tidak adanya yang meminta ganti rugi kepada PT Pharos karena menggunakan produk Viostin Ds. Dan pertanggungjawaban yang dilakukan PT Pharos adalah dengan suka rela melakukan penarikan produk yang ada di pemasaran.

\section{DAFTAR PUSTAKA}

\section{Buku}

Hadjon, Philipus M. (1987). Perlindungan Hukum Bagi Rakyat Indonesia. Surabaya: PT Bina IImu.

Sari, Elsi K., \& Simangungso, Advendi. (2007). Hukum Dalam Ekonomi. Jakarta: Gransido.

Miru, A. (2011). Prinsip-Prinsip Pelindungan Hukum Bagi Konsumen Di Indoensia. Jakarta: Rajagrafindo.

Miru, Ahmadi., \& Yodo, Sutarman. (2015). Hukum Perlindungan Konsumen. Jarkarta:

Rajagrafindo.

Nurmadjito. (2000). Kesimpulan Perangkat Perundang-undangan Tentang Perlindungan Konsumen di Indonesia. Bandung: Mandar Maju.

Rahardjo, S. (2000). IImu Hukum. Bandung: PT Citra Aditya Bakti.

Samsul, I. (2004). Hukum Perlindungan Konsumen Kemungkinan Penerapan Tanggung Jawab Mutlak. Universitas Indonesia Fakultas Hukum.
Undang-Undang Dan Surat Keputusan

Keputusan Kepala Badan Pengawas Obat Dan Makanan Republik Indonesia Nomor HK. 00.05.23.3644

Keputusan Menteri Agama R.I.Nomor 518 Tahun 2001

Keputusan Menteri Kesehatan RI Nomor : 924/Menkes/SK/VIII/1996

Peraturan Pemerintah No 69 Tahun 1999

Peraturan Pemerintah Republik Indonesia Nomor 69 Tahun 1999

Surat Keputusan Lembaga Pengkajian Pangan, Obat-obatan dan Kosmetika MUI, Nomor : SK74/Dir/LPPOM MUI/XI/09

Undang-Undang 8 Tahun 1999

Undang-undang 18 Tahun 2012

Undang-Undang 35 Tahun 2009

\section{Artikel Dan J urnal}

Asri. (2016). Perlindungan Hukum Bagi Konsumen Terhadap Produk Yang Tidak Bersetifikat Halal. J urnal IUS, Vol.4,(No. 2), pp.1-21.

Barkatullah, Abdul H. (2007). Urgensi Perlindungan Hak-Hak Konsumen Dalam Transaksi Di ECommerce. J urnal Hukum IUS QUIA IUSTUM, Vol.14, No.(2), pp.247-270.

Fadhly, F. (2013). Ganti Rugi Sebagai Perlindungan Hukum Bagi Konsumen Akibat Produk Cacat. Arena Hukum, Vol.6,(No.2), pp.152-289.

Nggeboe, F. (2015). Penyelesaian Hukum Bagii Konsumen Dari Produk Cacat Menurut Undang-Undang Nomor 8 Tahun 1999. Legalitas, Vol. 7, (No.2), pp.44-73. 
Jurnal Pembangunan Hukum Indonesia

Volume 1, Nomor 1, Tahun 2019

Nurbaiti, S. (2013). Aspek Yuridis Mengenai Product Liability Menurut Undang-Undang Perlindungan Konsumen (Studi Perbandingan Indonesia - Turki). J urnal Hukum Prioris, Vol.3, (No.2), pp.71-94.

Rusli, T. (2012). TanggungJawab Produk Dalam Hukum Perlindungan Konsumen. Pranata Hukum, Vol.7, (No.1), pp.79-88.

Darnela, Lindra., \& Saraspeni, Wiji. (2016). Perlindungan Konsumen terhadap Hak Atas Informasi Harga Pada Menu Makanan, dalam Perspektif Undang-Undang Nomor 8 Tahun 1999 tentang Perlindungan Konsumen ( Studi Kasus di Warung Makan pada Kawasan Malioboro ). Supermasi Hukum, Vol.5, (No.1), pp. 163-189. Retrieved from https://www.aifisdigilib.org/uploads/1/3/4/6/13465004/8wiji_saraspeni-uin_sunan_kalijaga.pdf

Triasih, Dharu., Heryanti, B. Rini., \& Kridasaksana, Doddy. (2016). Kajian Tentang Perlindungan Hukum Bagi Konsumen Terhadap Produk Makanan Bersertifikat Halal. J urnal Dinamika Sosial Budaya, Vol.18,(No.2), pp.214-225.

\section{Web Dan Internet}

Adisasmito, W. (2008). Analisis Kebijakan Nasional MUI dan BPOM dalam Labeling Obat dan Makanan. Retrieved November 16, 2018, from https://staff.blog.ui.ac.id/wikua/files/2009/02/ke bijakan-nasional-mui-dan-bpom-dalamlabeling-obat-dan-makanan_edited.pdf Andriyani, L. (2016). Tanggung Jawab Pelaku Usaha Pengobatan Tradisional Di Bidang pelayanan
Program Studi Magister Ilmu Hukum Fakultas Hukum Universitas Diponegoro

Kesehatan Untuk Memenuhi Hak-Hak Pasien Sebagai Konsumen Jasa. Retrieved from http://ejournal.uajy.ac.id/10615/1/JurnalHK105 68.pdf

Ilham, R. A. (2015). Perlindungan Hukum Terhadap Konsumen Atas Penjualan Obat-Obatan llegal Secara Online. Hukum. Malang. Retrieved fromhttp://hukum.studentjournal.ub.ac.id/index. php/hukum/article/view/911/902

Wijaya, Y. P. (2009). Fakta Ilmiah Tentang Keharaman Babi. Retrieved from https://www.purwantowahyudi.com/Ebook/Isla m/fakta-imiah-tentang-keharaman-babiyogapw.pdf 